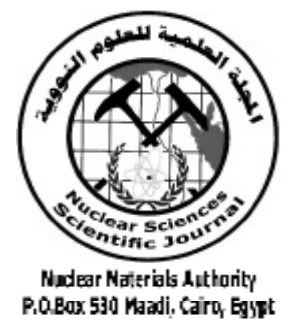

ISSN 2314-5609

Nuclear Sciences Scientific Journal

vol. 4, p 85- 102

2015

\title{
MINERALOGY, RADIOACTIVITY AND REE-GEOCHEMISTRY OF BATOGA MONZOGRANITE AND ASSOCIATED PEGMATITE, SOUTHEASTERN DESERT, EGYPT
}

\author{
ABDEL MOEZ, A. SADEK and ABDEL HADI A. ABBAS \\ Nuclear Materials Authority, P.O. Box 530, El-Maadi, Cairo, Egypt
}

\begin{abstract}
The studied area lies in the southern part of the Eastern Desert of Egypt to the southwest of Ras Benas. This area is covered by metagabbros, tonalite and monzogranite. The pegmatites occur as elongated, small pockets and lenses in the monzogranite and display sharp contacts with the host granite. In all cases, the pegmatites are characterized by obvious simple zonation.

The radiometric studies of monzogranite and associated pegmatite samples show that these rocks are uraniferous, where their average equivalent uranium contents are $12 \mathrm{ppm}$ and $134 \mathrm{ppm}$, respectively. The uraniferous character was confirmed by the average eTh/eU ratios ( 1.13 and 0.96 , respectively). The average ratios of $\mathrm{P}_{\text {factor }}$ of the studied granites and associated pegmatites are more than one (1.89 and 16.35, respectively), indicating disequilibrium in U-decay series due to addition of uranium to these rocks. The present study proved that the presence of uranothorite, uranophane and the uranium-bearing minerals such as zircon, monazite, allanite and fluorite are responsible for both $U$ and Th contents in the studied granite and associated pegmatite.

The normalized REE pattern of the monzogranite and associated pegmatite have similar geochemical characteristics. Where the REE patterns show a LREE relatively enriched feature with strong negative Eu-anomaly. The characteristic high LREE relative to HREE of the analyzed samples is attributed to the presence of the allanite, monazite and apatite minerals. The slightly positive $\mathrm{Tb}$ anomaly in the studied granites attributed to its preferential accommodation within the fluorite structure.
\end{abstract}

\section{INTROUDUCTION}

The younger granites are widely distributed all over the Egyptian Shield, constituting approximately $30 \%$ of the plutonic assemblage. Their abundance relative to the older granitoids increases from 1 to 4 in the south to approximately 1 to 1 in the north of the Eastern Desert (Stern 1979) . The granitic rocks are known to have much higher uranium content than the other common rock types. Some younger granites in Egypt host potential uranium mineralization. Such uranium mineralization seems to have an intimate relationship with the hydrothermal alteration (Mohamed, 1995, Shalaby, 1996, El Bayoumi et al., 1999, Assaf et al., 1999, Ammar and Abd El Wahed, 2000 and Dawood and Abd El Naby, 2001, Sadek, 2005).

The studied area lies in the southern part of the Eastern Desert of Egypt to the southwest of Ras Benas. It is located between longitudes $35^{\circ} 20^{\circ}$ and $35^{\circ} 25^{\circ} \mathrm{E}$, and latitudes $23^{\circ} 47^{\circ}$ and $23^{\circ} 52^{\circ} \mathrm{N}$ covering an area of about 80 $\mathrm{km}^{2}$. The area of study is covered by metagabbros, tonalite and monzogranites (Fig.1).

The present study deals with the geology, 
petrography, radioactivity, mineralogy and rare earth geochemistry of the granitic rocks of Gabal Batoga in order to discuss the genesis of the radioactive anomalies.

\section{FIELD AND PETROGRAPHIC OBSERVATION}

The study area is covered by metagabbros, tonalite and younger granites.

The Tonalite show lows resistance to weathering. They are characterized by cavernous, exfoliation and bouldary weathering and monumental like -shape. Also in places, some irregular shaped enclosed of microgranular mafic rocks enclosed in these rocks.

Monzogranite is marked by relatively higher mountain, with prominent peak up to $801 \mathrm{~m}$ above sea level. The rocks are equigranular, medium-grained with pale buff to white colors, and have rounded pluton and show intrusive contacts to the older rocks. Generally, the monzogranite intrudes the older rocks by sending offshoots invading them. Sometimes, it carries the tonalite as roof pendants (Fig.2). The studied monzogranite is highly weathered, showing exfoliation bouldary with characteristic monumental shapes. The pluton of younger granite is traversed by many dyke swarms of mafic (andesite) and felsic (aplite and microgranite) composition, trending mainly in the NW-SE and NE-SW directions (Fig.3).

Pegmatites are commonly encountered in the studied monzogranite. They are found as small lenticular and oval-shaped pockets of limited extension near the intersections of the NE-SW and NW-SE faulting systems (Figs4\&5). Their dimensions are about 2 to $5 \mathrm{~m}$ in width and 10 to $300 \mathrm{~m}$ in length. They are very coarse-grained rocks of pink color and are composed mainly of megacrysts of potash feldspar crystals (70\%), milky quartz $(20 \%)$, and plagioclase $(8 \%)$, together with subordinate mafic minerals mainly biotite and muscovite. Radiometric field measurements indicated that the radioactivity of pegmatites is more than twice that of their enclosing granitic

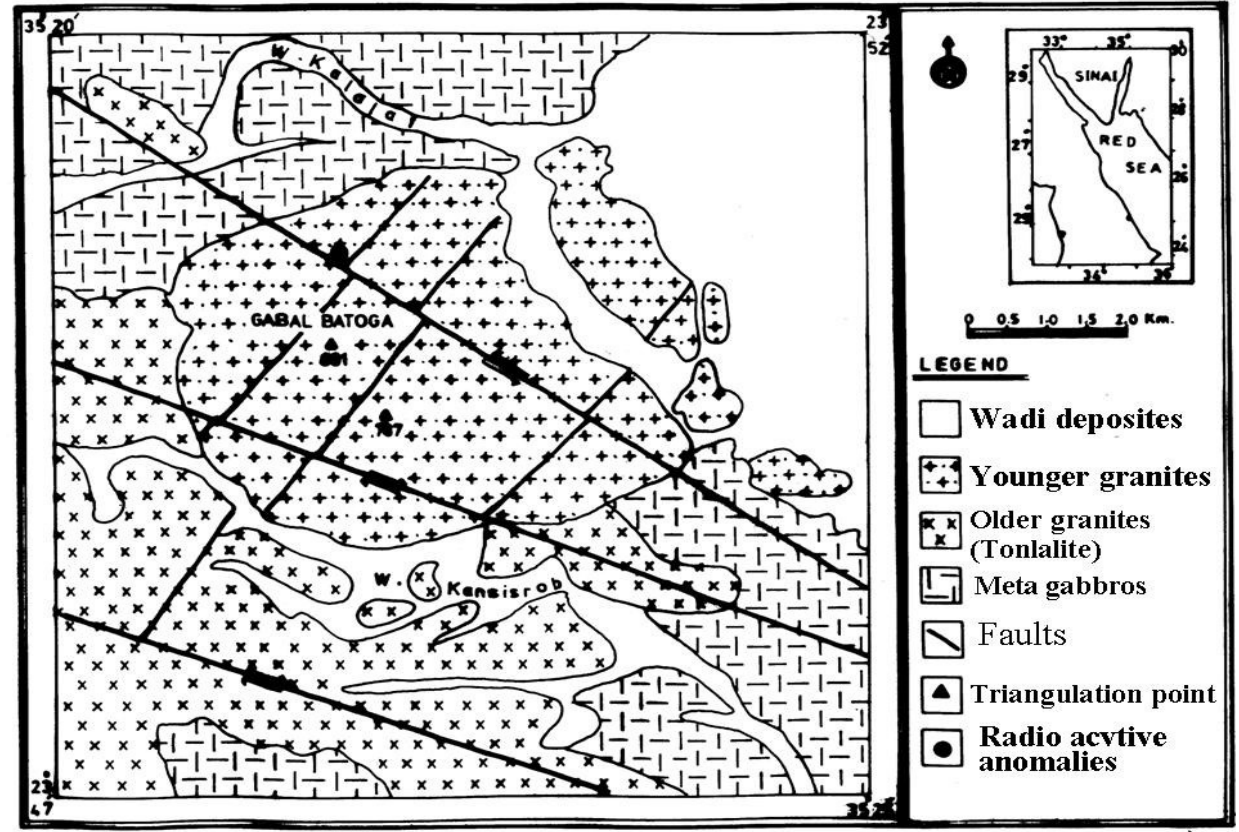

Fig.1: Geologic map of Batoga Area, Central Eastern Desert, Egypt 
rocks. They are characterized by high contents of radiometric measurements with visible mineralizations mainly of metallic black and brown color minerals, as well as yellow colored uranium minerals and disseminated green and violet fluorite. The studied area are traversed by many faults in different directions and types. These are either concomitant with wadis and drainage lines or cutting the country rocks and having NE-SW (older) and NW-SE (younger) directions.

\section{PETROGRAPHY}

The microscopic investigations of the studied monzogranites indicate they are mainly composed of quartz $(\sim 30 \%)$, plagio-

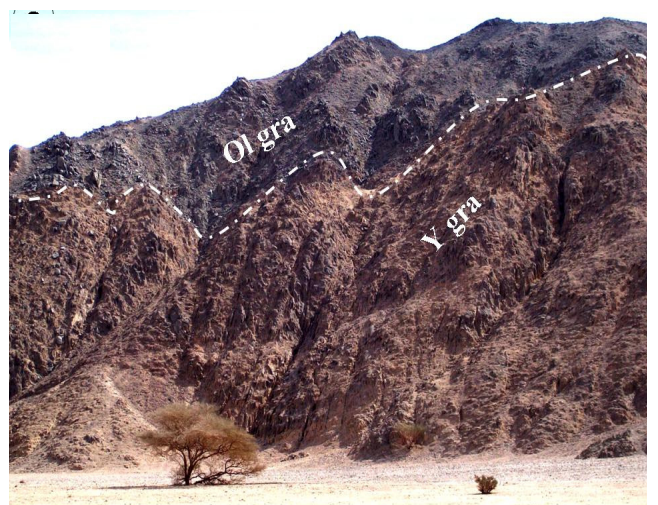

Fig.2:Photograph showing younger granites (Ygra) intruding and carrying older granite (Ol gra) as roof pendants, Looking $\mathrm{N}$.

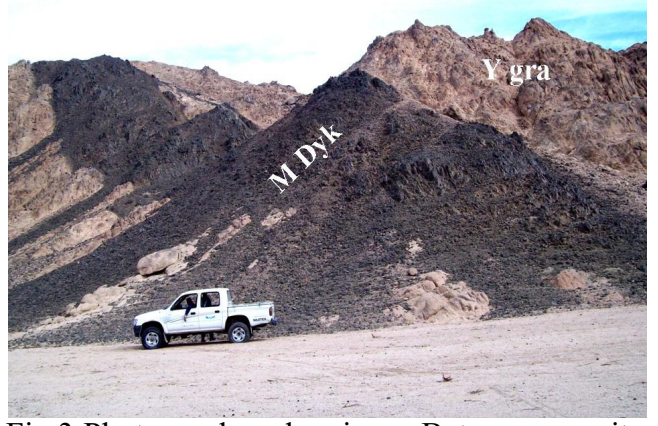

Fig.3:Photograph showing Batoga granites dissected by mafic dyke swarms( M Dyk), Looking N.

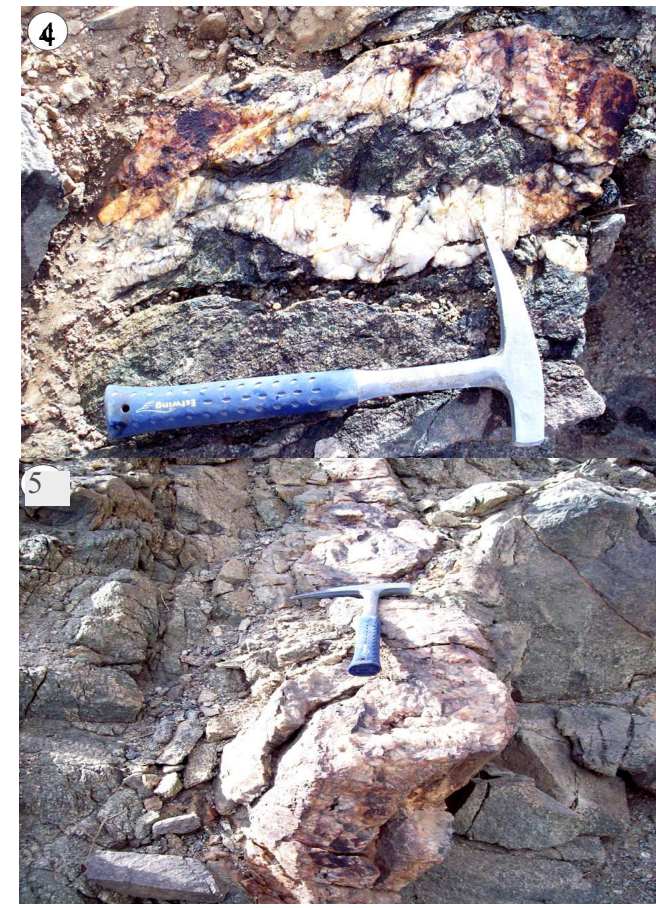

Fig.4\&5:Photograph showing Lenticular shaped of pegmatite pockets in Batoga granites, Looking N.

clase $(\sim 32 \%)$, K- feldspars $(\sim 26 \%)$, biotite, hornblende and muscovite as mafic minerals $(\sim 10 \%)$. The common accessory minerals are zircon, allanite, fluorite, monazite, apatite and opaques.

Quartz, commonly occurs as anhedral crystals of variable sizes and show undulose extinction. Minute quartz crystals occupy the interstitial spaces between feldspars. Sometimes, cataclastic deformation, granulation, recrystallization are observed in many crystals. The presence of myrmekitic and graphic texture (Fig.6) is a reflection of mineral replacement and reaction features affecting of this monzogranite (Shelley, 1993).

$K$-feldspar occurs as subhedral to anhedral crystals of microcline, microcline perthite and orthoclase perthites as well as antiperthite. Orthoclase perthite occurs as patchy and flame 


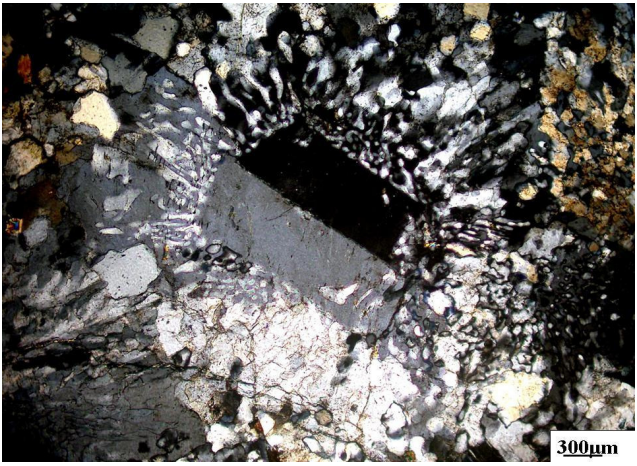

Fig.6: Photomicrograph of Batoga monzogranite showing Quartz intergrown with feldspar developing myrmekitic and graphic texture

types. Microcline perthite has both albite and percline twinning which together form what is known tartan pattern (Fig.7).

Plagioclase occurs as oligoclase which is the most abundant essential mineral. It is represented by subhedral to euhedral prismatic crystals of variable sizes with distinct carlsbad and albite twinning and sometimes occurs as zoned crystals (Fig.8). It is suassuratized, and muscovitized along core and some crystal altered along peripheries are observed (Fig.9).

Biotite and muscovite are the most abundant mafic minerals. Biotite occurs as subhedral flakes of brown color. Some biotite crystals poikilitically enclose zircon that is surrounded by the pleochroic haloes due to radiogenic effects (Fig.10). In some places biotite altered to chlorite. Muscovite is subordinate mineral and found as minute amount as a primary mineral associated with opaques and also as a secondary mineral resulting from the alteration of plagioclase and biotite. Hornblende occurs as greenish subhedral crystals, showing simple twinning, partially altered to chlorite and also corroded by quartz and feldspar (Fig.11).

Zircon occurs as fine prismatic metamict crystals intimately associated with biotite and feldspars (see Fig.10). Apatite occurs as fine rod-like and/or prismatic crystals (Fig.12). Allanite occurs as euhedral crystals, yellowish brown masked interference colors (Fig. 13). The petrographic investigation indicates

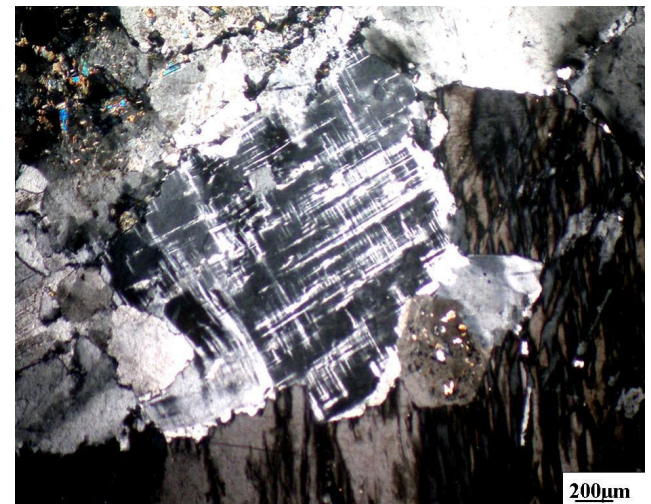

Fig.7: Photomicrograph of Batoga monzogranite showing microcline and microcline perthite

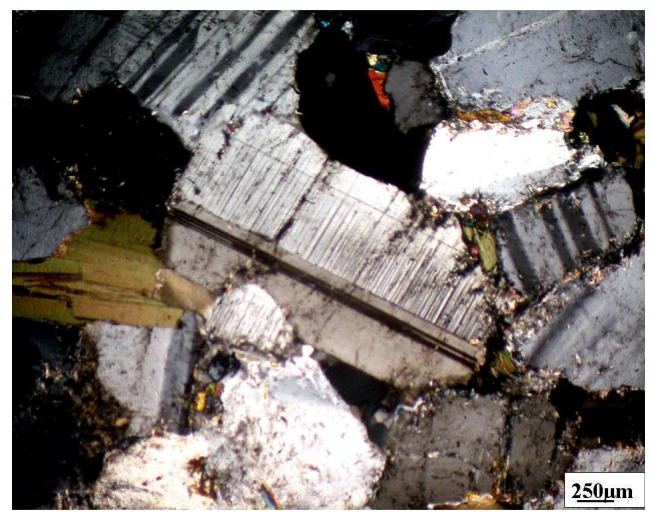

Fig.8: Photomicrograph of Batoga monzogranite showing plagioclase corroded by quartz

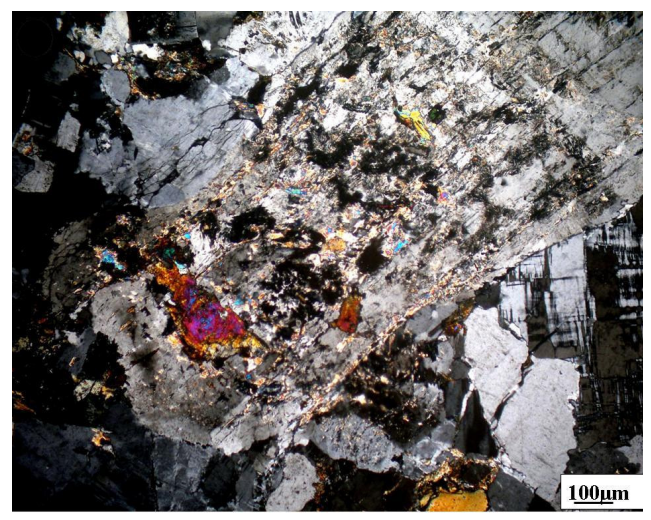

Fig.9: Photomicrograph of Batoga monzogranite showing plagioclase showing partial alteration to suassurite and muscovite 


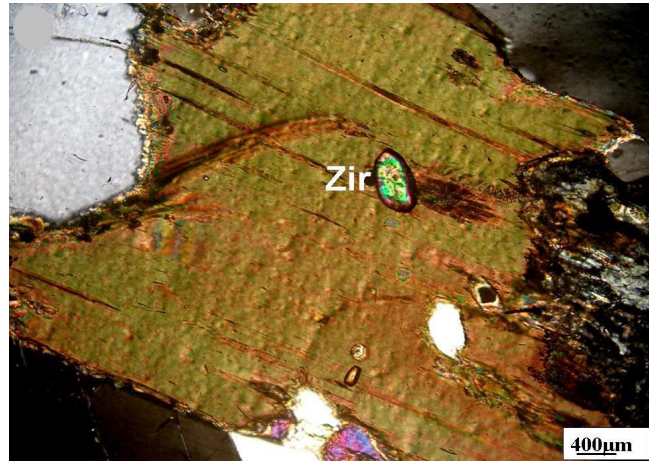

Fig.10: Photomicrograph ofBatoga monzogranite showing biotite flakes enclose zircon surrounded by the pleochroic haloes

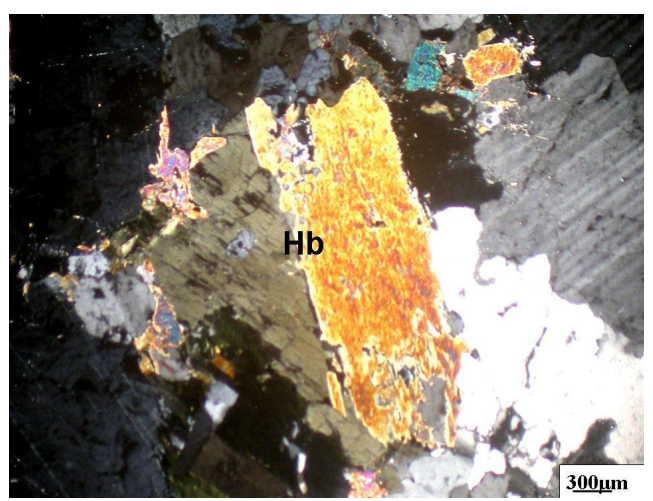

Fig.11:Photomicrograph of Batoga monzogranite showing hornblende associated with plagioclase,

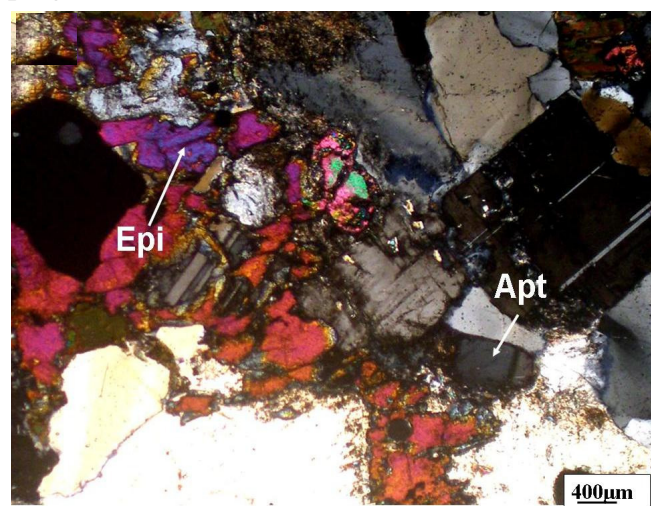

Fig.12: Photomicrograph of Batoga monzogranite showing apatite associated with secondary epidote

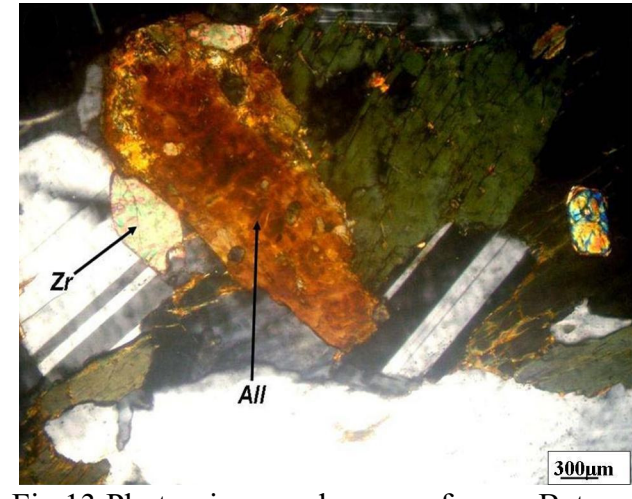

Fig.13:Photomicrograph of Batoga monzogranite showing allanite crystals associated with plagioclase and zircon.

that the monzogranite of Batoga granites belong to the subsolvus type (Deer et al., 1962), which was crystallized under relatively high water pressure conditions.

Pegmatite is mainly composed of K-feldspar, plagioclase, and quartz in addition to muscovite and biotite. The accessory minerals are mainly zircon, monazite, allanite, and fluorite. K-Feldspars occur as orthoclase, microcline and microcline perthite. Perthite and antiperthite form subhedral to euhedral prismatic megacrysts corroded by quartz (Fig.14). Plagioclase $\left(\mathrm{An}_{20}\right)$ exhibits slight deformation, suassuratization and muscovitization in some crystals (Fig.15). Quartz is cracked, in places filled with iron oxides and yellowish color radioactive minerals (uranophane?) (Fig.15). Biotite occurs as euhedral flaky crystals of brownish green color (Fig. 16). The muscovite flakes exhibit different interference color (Fig. 17).

\section{RADIOACTIVITY}

Uranium occurs in the nature in several valance states, in which tetravalent $\left(\mathrm{U}^{+4}\right)$ and hexavalent $\left(\mathrm{U}^{+6}\right)$ are the most common ones, whereas thorium exists only in the tetravalent $\left(\mathrm{Th}^{+4}\right)$ state. The $\mathrm{U}^{+4}$ has an ionic radius close to the ionic radii of $\mathrm{Th}, \mathrm{Ca}, \mathrm{Na}, \mathrm{Zr}, \mathrm{Nb}, \mathrm{Y}$, $\mathrm{Ce}, \mathrm{Pb}^{2}$ and the rare earth elements. Therefore, $\mathrm{U}^{+4}$ can substitute these elements in the 


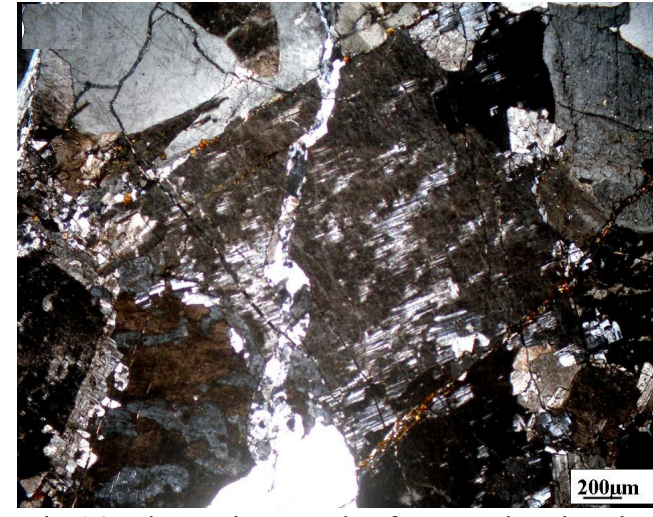

Fig.14: Photomicrograph of pegmatite showing megacrysts of perthite and antiperthite corroded by quartz

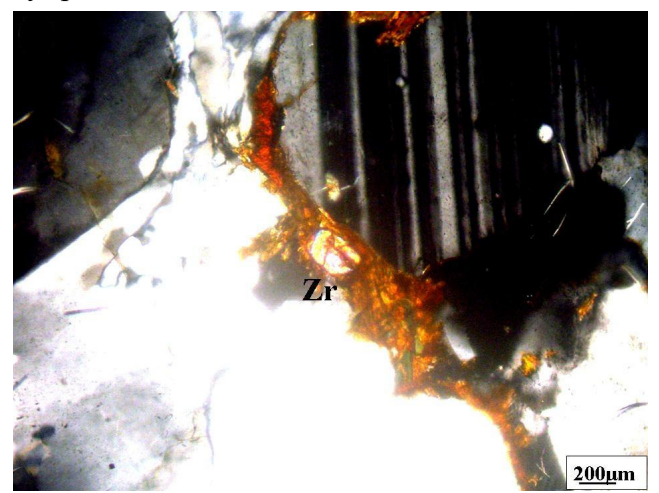

fFig.15: Photomicrograph of pegmatite showing plagioclase exhibits muscovitization corroded by quartz

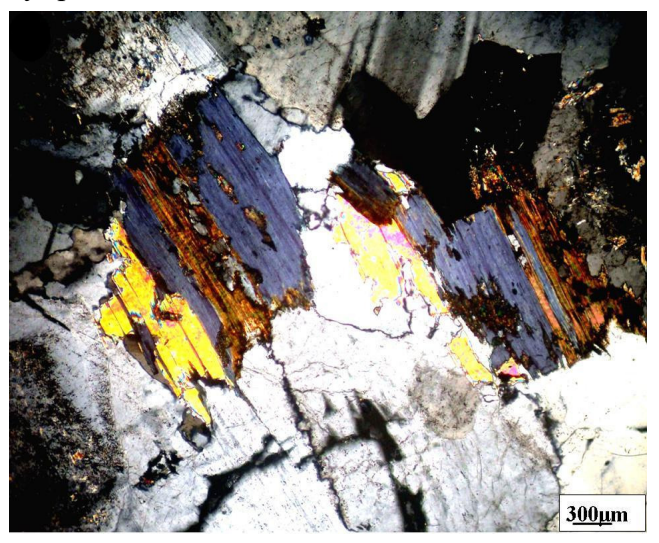

Fig.16: Photomicrograph of pegmatite showing biotite flakes with chlorite

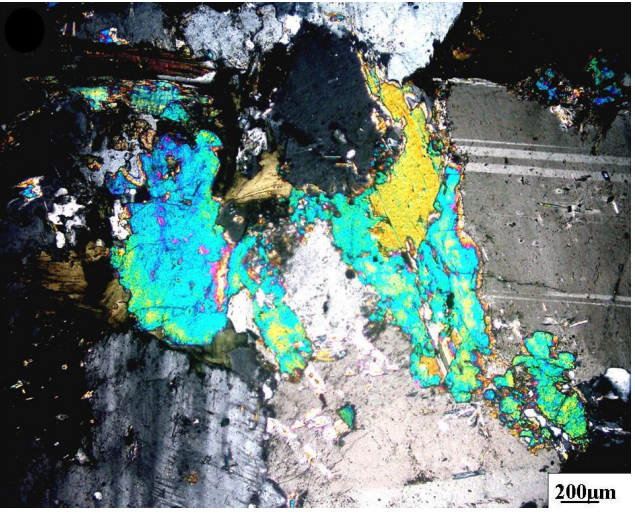

Fig.17: Photomicrograph of pegmatite showing Muscovite flakes exhibit different interference color

structure of their minerals (Gascoyne, 1982). $\mathrm{U}^{+4}$ is insoluble in water and occurs mainly in primary minerals, but when oxidized to $\mathrm{U}^{+6}$ becomes soluble in water and forms secondary minerals. Thorium is insoluble in water, occurs mainly in primary minerals, and is rarely leached by secondary processes.

Field measurements show a slight increase in radioactivity of the examined Batoga monzogranite and associated pegmatite. Uranium, thorium, radium and potassium were measured by using four energy regions representing ${ }^{234} \mathrm{Th},{ }^{212} \mathrm{~Pb},{ }^{214} \mathrm{~Pb}$ and ${ }^{40} \mathrm{~K}$ at $93 \mathrm{kV}, 239 \mathrm{kV}$, $352 \mathrm{kV}$, and $1460 \mathrm{kV}$ for uranium, thorium, radium and potassium, respectively. The measurements were carried out in sample plastic containers, cylindrical in shape, $12.6 \mathrm{~cm}^{3}$ in volume with $9.5 \mathrm{~cm}$ average diameter and $3 \mathrm{~cm}$ height. The rock sample was crushed as fine as about $1 \mathrm{~mm}$ in grain size, and then the container was filled with about 300-400 gm of the crushed sample sealed well and left for at least 21 days to accumulate free radon to attain radioactive equilibrium. The relation between the percentage of ${ }^{222} \mathrm{Rn}$ accumulation and time increased till reaching the steady stage after about 38 days (Matolin, 1991).

Eighteen samples (8 samples from monzogranite and 10 samples from associated pegmatite) were radiometrically analyzed 
to determine the equivalent uranium (eU) equivalent thorium (eTh), radium and potassium contents (Table.1). The eU contents of the analyzed monzogranite samples range from $8 \mathrm{ppm}$ to $20 \mathrm{ppm}$ with an average 12 and the eTh contents range from $10 \mathrm{ppm}$ to $23 \mathrm{ppm}$ with an average 13.3. Mean value of uranium contents in the studied granites is slightly higher than the average of granitic rocks (4.75 ppm) given by Rogers and Adams (1969). eTh/eU ratios of these granites range from 0.93 to 1.25 with an average 1.13 .

The eU contents of the analyzed pegmatite samples range from $28 \mathrm{ppm}$ to $355 \mathrm{ppm}$ with an average 134 and the eTh contents range from $24 \mathrm{ppm}$ to $210 \mathrm{ppm}$ with an average 97.6 as given in Table (1). It is worthy to mentioned that the altered granites belong to high-thorium, high-uranium granitic rocks where uranium is mostly located in the Th-rich accessory minerals as monazite, zircon and allanite. The eTh/eU ratios of these samples range from 0.52 to $1.78 \mathrm{ppm}$ with an average 0.96 . The very low eTh/eU $<1$ in pegmatites indicate strong addition of uranium during post-magmatic stages (Charbonneau, 1982).

Table 1: eU and eTh contents in (ppm) of the studied granite and pegmatite

\begin{tabular}{|c|c|c|c|c|c|c|c|}
\hline R.T & S.no. & eU(ppm) & eTh(ppm) & $\mathrm{eTh} / \mathrm{eU}$ & eU/Ra & $\mathrm{K} \%$ & $\operatorname{Ra}(\mathrm{eU})$ \\
\hline \multirow{9}{*}{ 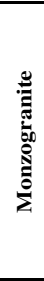 } & 1 & 14 & 13 & 0.93 & 2.0 & 3.5 & 7.0 \\
\hline & 2 & 10 & 12 & 1.2 & 1.37 & 3.0 & 7.3 \\
\hline & 3 & 8.0 & 10 & 1.25 & 1.60 & 3.2 & 5.0 \\
\hline & 4 & 9.7 & 11 & 1.13 & 1.76 & 3.4 & 5.5 \\
\hline & 5 & 11 & 13 & 1.18 & 1.77 & 3.3 & 6.2 \\
\hline & 6 & 20 & 23 & 1.1 & 2.94 & 4.0 & 6.8 \\
\hline & 7 & 9.0 & 10 & 1.11 & 1.55 & 3.0 & 5.8 \\
\hline & 8 & 13 & 14.5 & 1.12 & 2.10 & 3.6 & 6.2 \\
\hline & Av. & 11.8 & 13.3 & 1.13 & 1.89 & 3.38 & 6.23 \\
\hline \multirow{11}{*}{ } & 1 & 35 & 28 & 0.8 & 4.86 & 4.0 & 7.2 \\
\hline & 2 & 28 & 36 & 1.29 & 4.00 & 4.2 & 7.0 \\
\hline & 3 & 18 & 24 & 1.33 & 2.77 & 3.8 & 6.5 \\
\hline & 4 & 54 & 56 & 1.04 & 7.20 & 3.6 & 7.5 \\
\hline & 5 & 63 & 112 & 1.78 & 8.29 & 4.0 & 7.6 \\
\hline & 6 & 98 & 80 & 0.82 & 12.25 & 3.6 & 8.0 \\
\hline & 7 & 345 & 180 & 0.52 & 40.59 & 3.8 & 8.5 \\
\hline & 8 & 225 & 169 & 0.75 & 27.44 & 3.0 & 8.2 \\
\hline & 9 & 355 & 210 & 0.59 & 40.80 & 3.4 & 8.7 \\
\hline & 10 & 122 & 80.5 & 0.66 & 15.25 & 3.1 & 8.0 \\
\hline & Av. & 134 & 97.6 & 0.96 & 16.35 & 3.65 & 7.72 \\
\hline
\end{tabular}

The U-Th diagram of the studied granites and pegmatites shows a positive correlation which indicates that the behavior of $\mathrm{U}$ and $\mathrm{Th}$ was controlled by post-magmatic processes (Fig.18) (Simpson et al., 1979; Raslan et al., 2010a and b). The variation of Th and $\mathrm{U}$ against $\mathrm{Th} / \mathrm{U}$ ratio shows a negative correlation with $U$ and $T h$, which has confirmed the idea that $U$ and Th enrichment in these anomalies was controlled by magmatic processes or deuteric ones (Fig.19 and 20) (Simpson Op.Cit). It is important to observe a slight increase in uranium concentration with increasing potassium concentration in monzogranites on the contrary to pegmatites (Fig.21), which is mostly due to the mobility of uranium as reported by Anjos et al. (2005). Thorium displays positive correlation with potassium in the studied monzogranites suggesting magmatic controlling processes and negative correlation with associated pegmatites probably due to the effect of hydrothermal alteration processes which led to the formation of clay minerals at the expense of feldspars (El-Feky et al., 2011). In general, low $\mathrm{eTh} / \mathrm{K}$ ratios are an excellent indicator of potassium alterations (Shives et al., 1995). Ratios of eTh/eU $<2$ are highly suggestive of relative uranium enrichment but ratios $>7$ indicate preferential removal of uranium, possibly by leaching (Adams and Weaver, 1958). The cross plot of eTh/eU and $\mathrm{eTh} / \mathrm{K}$ ratios presented in (Fig.23). exhibit that granite samples lie in the fixed-U sector while pegmatite samples lie in the leached-U sector with the exception of one sample (Anjos et al., 2005).

\section{Radioactive Equilibrium}

According to Reeves and Brooks (1978), uranium ( $\mathrm{U}^{238}$ series) attains the equilibrium state in nearly 1.5 M.a. Cathelineau and Holliger (1987) stated that uranium mineralization is affected by different processes. Leaching, mobility and redistribution of uranium are affected by hydrothermal solutions and/or supergene fluids, which cause disequilibrium in the radioactive decay series in U- bearing rocks. The radioactive equilibrium of the 


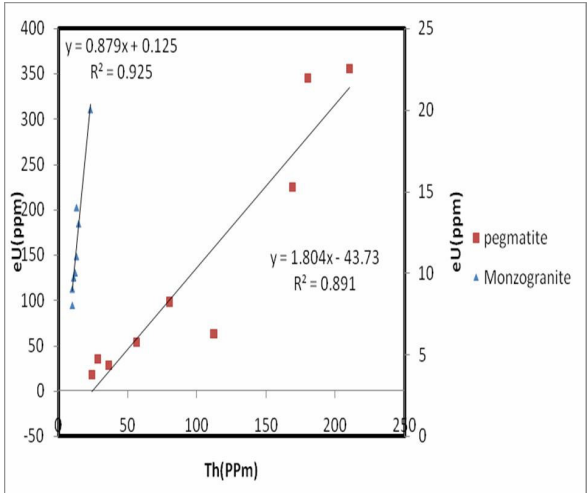

Fig.18: Variation diagram between eTh vs. eU of the studied monzogranite ( $\downarrow)$ and associated pegmatite ( $\mathbf{})$ in Batoga area.

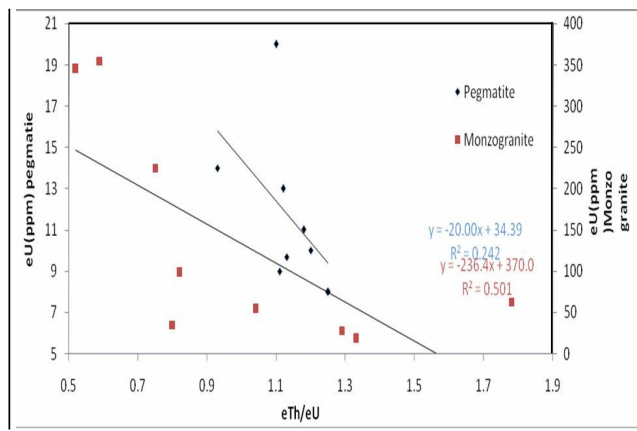

Fig. 19:Variation diagram between eU vs. eTh/u of the studied monzogranite ( $\downarrow)$ and associated pegmatite ( $\square)$ in Batoga area.

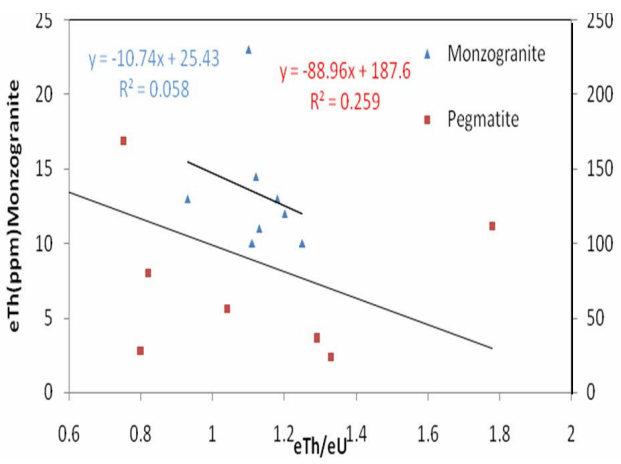

Fig.20:Variation diagram between eTh vs eTh/u of the studied monzogranite $(\diamond)$ and associated pegmatite ( $\mathbf{})$ in Batoga area.

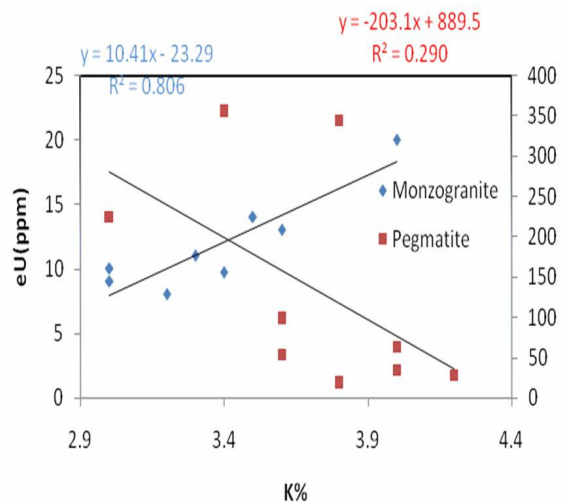

Fig.21:Variation diagram between eU vs K\% of the studied monzogranite $(\diamond)$ and associated pegmatite ( $\mathbf{})$ in Batoga area.

\section{k\%Th(ppm)}

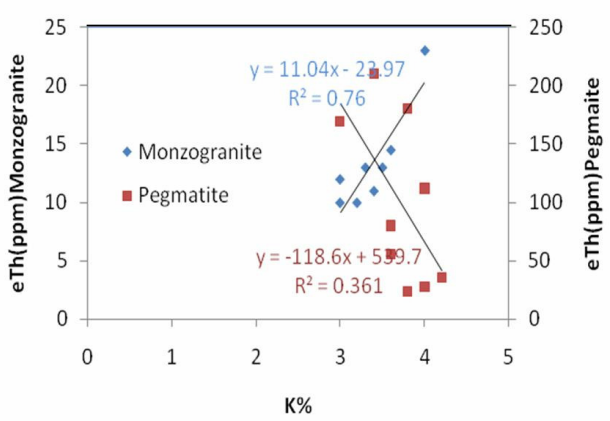

Fig.22:Variation diagram between eTh vs K\% of the studied monzogranite $(\diamond)$ and associated pegmatite ( $\square)$ in Batoga area.

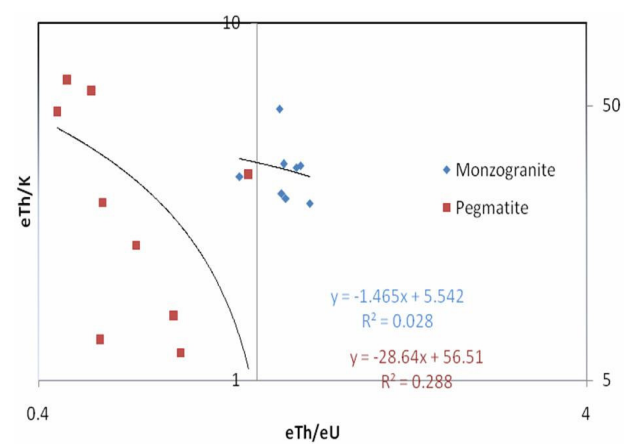

Fig.23:Variation diagram between $\mathrm{eTh} / \mathrm{K}$ vs. $\mathrm{eTh} / \mathrm{u}$ of the studied monzogranite $(\diamond)$ and associated pegmatite ( $\mathbf{})$ in Batoga area. 
studied granitic rocks can be determined by the calculation of equilibrium factor $(\mathrm{P})$ which is the ratio of radiometric uranium contents (eU) to the radium content $\mathrm{Ra}(\mathrm{eU}) ; \mathrm{P}_{\text {factor }}=\mathrm{eU} /$ Ra(eU) (Hussein, 1978; El-Galy, 1998; Surour et al., 2001).

The average ratios of $\mathrm{P}_{\text {factor }}$ of the studied granites and associated pegmatites are 1.89 and 16.35 , respectively. These ratios are more than one (Table1) indicating disequilibrium in U-decay series duet to uranium addition.

\section{MINERALOGY}

The heavy minerals were separated from the monzogranite and associated pegmatite by heavy liquid separation and picked as individual minerals under the binocular microscope. These minerals were identified by Environmental Scanning Electron Microscope (ESEM) back-scattered images, EDAX analyses and confirmed by X-ray diffraction (XRD) techniques. The EDAX examination revealed the presence of uranothorite, uranophane, $\mathrm{Nb}$ Ta minerals (columbite and exunite) and REEbearing minerals (allanite, monazite, apatite), zircon and fluorite.

\section{Uranothorite (U,Th)SiO}

It occurs as fine subhedral to anhedral bright inclusions inclusions. The ESEM analysis indicates that it consists essentially of $\mathrm{ThO}_{2}, \mathrm{SiO}_{2}$ and significant amount of $\mathrm{UO}_{2}$ reaching up to $7 \%$. Heinrich (1958) stated that, uranium is usually present in amount up to $10 \%$ in uranothorite. Other elements present in small to minor amounts such as $\mathrm{Ca}, \mathrm{Al}$, $\mathrm{Zr}$ and Fe Mg (Fig. 24).

\section{Uranophane $\mathrm{Ca}\left(\mathrm{UO}_{2}\right)_{2} \mathrm{Si}_{2} \mathrm{O}_{7}$}

Uranophane polymorphs of calcium uranium hydrate silicates; they are light yellow to orange in fibrous crystals with vitreous luster. It occurs as fissure filling or coating the altered K-feldspars. Fairly common in oxidation zones of most uranium deposits (Cesborn et al., 1993).

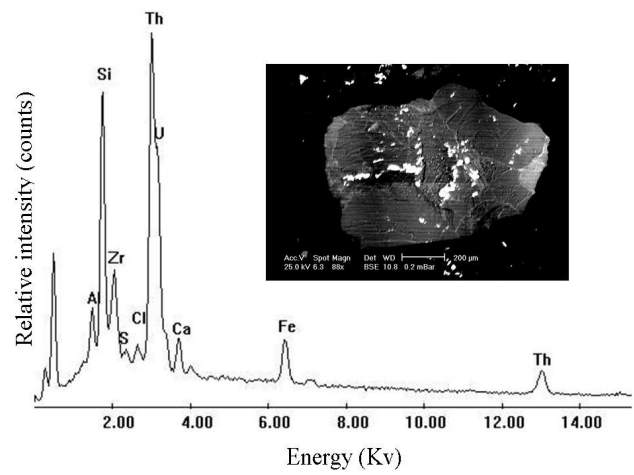

Fig.24:EDX and back scattered images of the studied uranothorite.

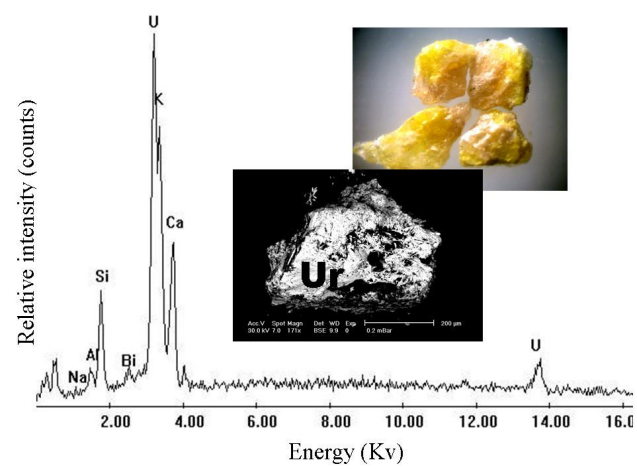

Fig.25:EDX and back scattered images of the studied uranophane.

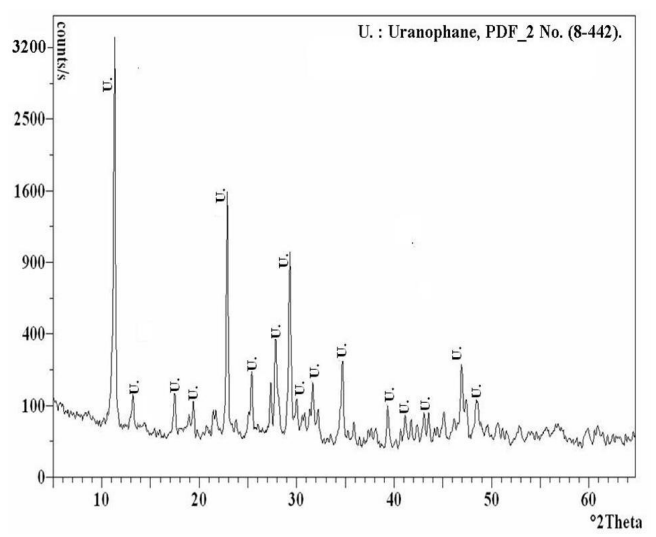

Fig.26:XRD pattern of the studied uranophane 
The ESEM-EDAX semiquantitative analysis of uranophane was composed of $\mathrm{Ca}, \mathrm{U}$ and $\mathrm{Si}$ confirmed by X-ray diffraction (Fig.25\&26) respectively. The uranium may be! derived from altered primary radioactive minerals, while calcium and silica are available in the aqueous solutions penetrating shear zone. Calcium can be liberated from altered plagioclase, calcite and silica which liberated during Kaolinitization of feldspars.

$\mathrm{Ca}^{+2}+2 \mathrm{UO}_{2}+2 \mathrm{SiO}_{2}+6 \mathrm{H}_{2} \mathrm{O}+3 \mathrm{O}^{2-} \leftrightarrow \mathrm{Ca}\left(\mathrm{UO}_{2}\right)_{2} \mathrm{Si}_{2} \mathrm{O}_{7} \cdot 6 \mathrm{H}_{2} \mathrm{O}$

In the study area, the absence of any trace of primary U-minerals and the abundance of the metamictized accessory minerals reflect that the metamictization is the main controlling process in the accumulation of the $\mathrm{U}$ which may be leached and redistributed along the fractures. Also, the leaching of the U-bearing minerals from the host granites is controlled by hydrothermal system operating in response to regional tectonism as well as the interaction with hydrothermal fluids $(\mathrm{Cu}-$ ney 1978; Abdel-Monem et al. 1998 and ElKammar et al. 2001) which become enriched in $\mathrm{U}$.

\section{Rare Earth-Bearing Minerals \\ Columbite (Fe,Mn)(Nb,Ta) ${ }_{2} \mathrm{O}_{6}$}

Ferrocolumbite grains were detected in the studied sample of pegmatite. The grains are generally black in color and possess metallic luster under binocular microscope. In the studied area, columbite found as blackish color; composed mainly of Fe-columbite $(\mathrm{Ta}<\mathrm{Nb}, \mathrm{Mn}<\mathrm{Fe})$ as revealed from the ESEM analysis. Several columbite crystals have been subjected to semiquantitative analyses using EDAX-scanning electron microscope. The EDAX -ESEM analyses show that both $\mathrm{Nb}$ and $\mathrm{Fe}$ are the essential components together with subordinate amount of Ta, U, Th and Mn (Fig.27).

\section{Euxenite (Y,Ca,Ce,U,Th)(Ti,Ta,Nb) ${ }_{2} \mathrm{O}_{6}$}

It is the predominant REE- bearing mineral in the pegmatite body occurring as disseminated stout prismatic crystals and sometimes

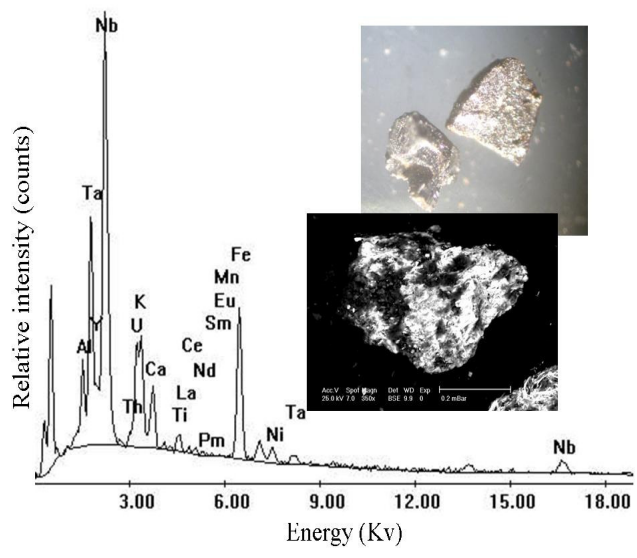

Fig.27:EDX and back scattered images of studied columbite

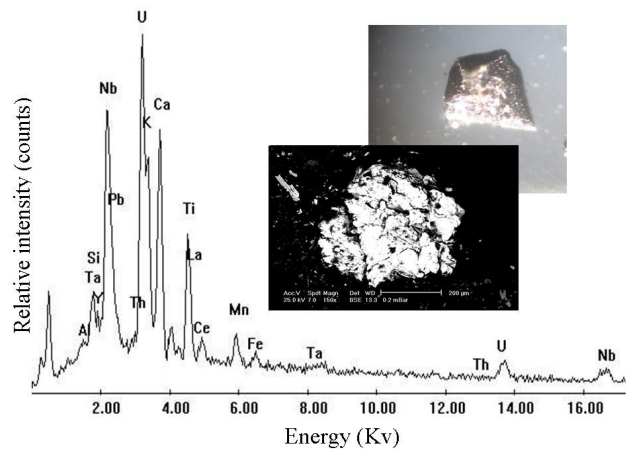

Fig.28:EDX and back scattered images of the studied exunite

occurs as flattened black crystals commonly metamict. Chemically, euxenite is considered as oxide or titanite-columbite of the type $\mathrm{AB}_{2} \mathrm{O}_{6}$. In the EDAX analyzed samples, $\sum \mathrm{Nb}+\mathrm{Ta}$ always exceeds Ti (Fig.28). In these minerals, $U$ varies between 23.5 to $28.5 \%$ and Th from nil to 2.3 , indicating the strong radioactive nature and their metamict state.

\section{Monazite (Ce,La, Th, ...) $\left(\mathrm{Po}_{4}, \mathrm{SiO}_{4}\right)$}

It is a phosphate mineral, composed essentially of $\mathrm{Ce}, \mathrm{La}$ and $\mathrm{Th}$. Th is usually present in substitution for Ce and/or La where $\mathrm{ThO}_{2}$ is about 10 to $12 \mathrm{wt} \%$. Y substitutes in small amount for $\mathrm{Ce} \& \mathrm{La}$ together with minor amounts of $\mathrm{Ca}$ and less abundantly $\mathrm{Mg}, \mathrm{Fe}^{\prime \prime}$, $\mathrm{Fe}^{\prime \prime \prime}$ due to oxidation. Al, Mn can be found 
and $\mathrm{U}$ is generally present in amount up to $\sim 1$ $\mathrm{wt} \% \mathrm{U}_{3} \mathrm{O}_{8}$. The $\mathrm{Si}$ has been found and ascribed to alteration or to admixed thorite but may be in part due to substitution of Si for P (Dana, 1963). Certain minerals such as monazite, bastnaesite and allanite are $\mathrm{Ce}$ - selective and

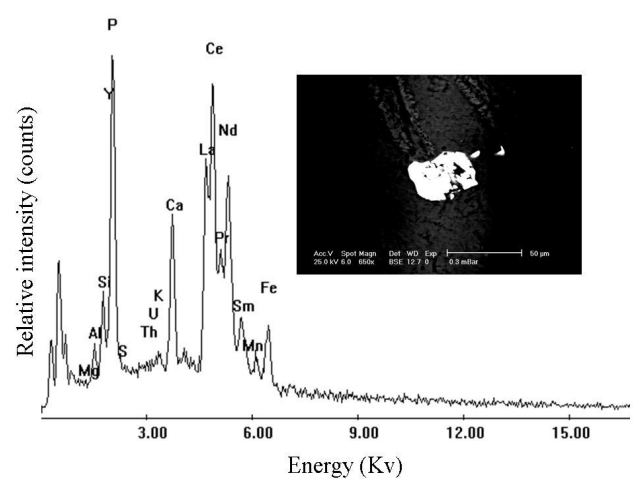

Fig.29:EDX and back scattered images of the studied monazite

prefer the LREE. Thus the Ce- group or LREE tend to be concentrated in highly fractionated acid rocks such as alkaline granites and pegmatites. In the studied granite, monazite occurs in minor amounts as minute crystals. The EDAX-ESEM analysis of monazite showed that $\mathrm{U}$ is low. The $\mathrm{U}$ may also replace some of the REE sites in the monazite (Hughes et al., 1991). The mineral composition contains a considerable amount of $\mathrm{Si}, \mathrm{La}, \mathrm{Ce}, \mathrm{Nd}, \mathrm{Al}$, $\mathrm{Ca}$, and $\mathrm{Mn}$ (Fig.29).

\section{Allanite $(\mathrm{Ce}, \mathrm{Ca}, \mathrm{Y})_{2}(\mathrm{Al}, \mathrm{Fe})_{3}\left(\mathrm{SiO}_{4}\right)_{3}(\mathrm{OH})$}

It is a member of the epidote group minerals of both hydrothermal and magmatic origin with rare earth elements substituting $\mathrm{Ca}$. It varies in color from light brown to black. Because of their similarity to the rare earth elements in ionic radius, $\mathrm{U}$ and $\mathrm{Th}$ may be incorporated in the structure of allanite. The metamictization of allanite produces an amorphous alteration product due to the destruction of the crystalline structure of allanite by the radioactive decay of its uranium and thorium contents. In the studied granites and pegmatites, allanite has been found as accessory mineral. They form

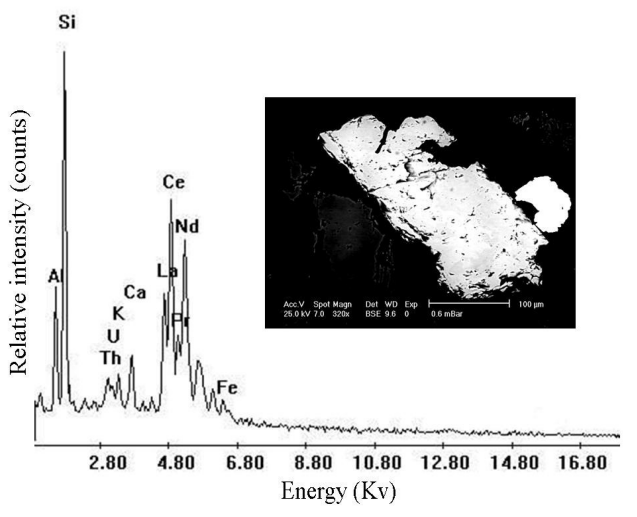

Fig.30:EDX and back scattered images of the studied allanite.

euhedral to subhedral zoned tabular prismatic crystals (may attain 4-6 $\mathrm{mm}$ in length) of reddish brown, intimately associated with biotite and zircon. Scan Electron Microscope (EDAX) show that the allanite is composed essentially of LREE, Ca, Fe, K, Al and $\mathrm{Si}$, as well as some $U$ and Th content (Fig.30). The radioactivity of allanite in the studied granites and pegmatites is much less important than that of zircon.

\section{Zircon $\left(\mathrm{ZrSiO}_{4}\right)$}

It occurs as euhedral prismatic grains characterized by pale to deep brown color and generally sub-translucent to opaque with dull luster. The EDAX data reflect the chemical composition of zircon is $\mathrm{ZrO}_{2}$ and $\mathrm{SiO}_{2}$ with significant amounts of $\mathrm{Th}, \mathrm{U}, \mathrm{Fe}, \mathrm{Al}, \mathrm{Ca}$ and Hf (Fig.31). The present study revealed that zircon and thorite can exist in partially solid solution state due to close up in the ionic radii of $\mathrm{Zr}$ and $\mathrm{Th}$ (Förster, 2006). Sometime, there is a clear intergrowth between zircon and thorite.

\section{Apatite $\mathrm{Ca}_{5}\left(\mathrm{PO}_{4}\right)_{3}(\mathrm{OH}, \mathrm{F}, \mathrm{Cl})$,}

It is a common accessory mineral in almost all igneous rocks. The common substitutions for $\mathrm{Ca}$ are $\mathrm{Sr}$ and rare earth elements and the lighter rare earth elements may be important in apatite of alkaline rocks. In the studied monzogranite and associated pegmatite, apa- 


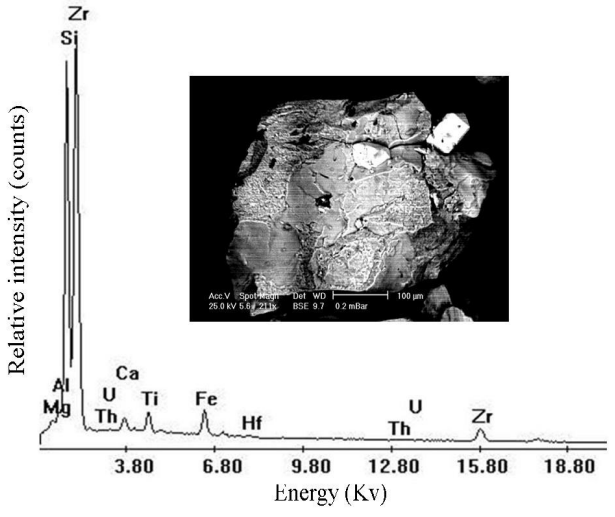

Fig.31: EDX and back scattered images of the studied zircon

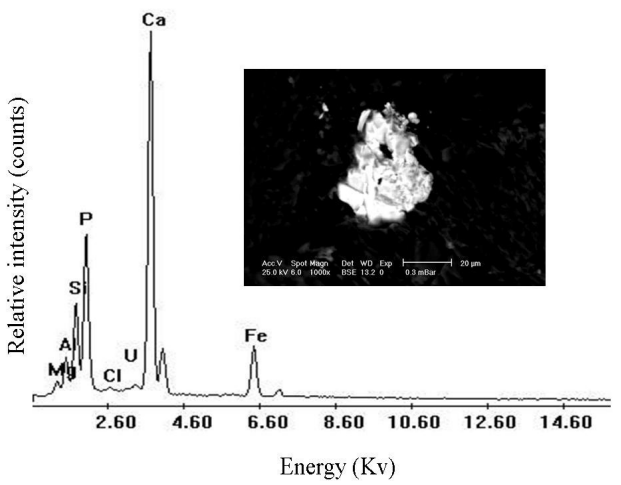

Fig.32: EDX and back scattered images of the studied apatite

tite occurs as massive and pale green rode-like crystals. The EDAX analysis of the studied samples shows that apatite is composed essentially of $\mathrm{Ca}$ and $\mathrm{P}$ with minor amount of $\mathrm{Si}$, $\mathrm{Al}, \mathrm{U}$ and $\mathrm{Fe}$. $\mathrm{U}$ substitutes for $\mathrm{Ca}$ in apatite structure (ionic radii are close to each other $\mathrm{Ca}=1.06$ ) (Fig.32).

\section{Fluorite $\left(\mathrm{CaF}_{2}\right)$}

It is found as anhedral crystals vary from colorless, violet to blackish color. In both colorless and violet fluorite varieties more than $70 \%$ of the rare earths content in fluorite is of HREE. The ESEM analysis of fluorite reveals that it is composed of $\mathrm{Ca}, \mathrm{F}, \mathrm{Si} \mathrm{Al}$, and U (Fig.33).

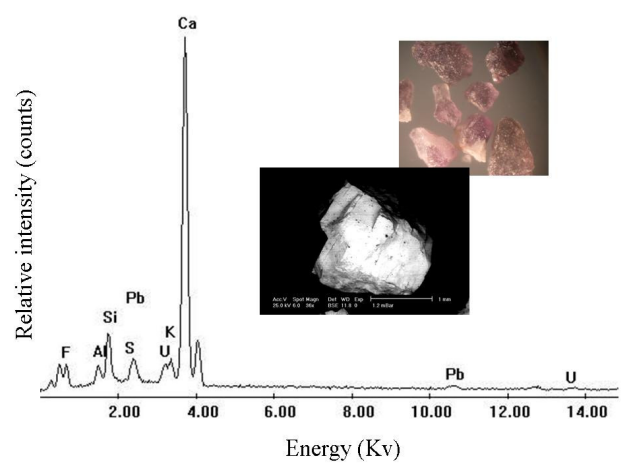

Fig.33: EDX and back scattered images of the studied fluorite

\section{RARE EARTH ELEMENTS (REES) GEOCHEMISTRY}

The REE are the most useful of all trace elements in the interpretation of the igneous rocks petrogenesis. They include the elements with atomic numbers in between 57-71 (La$\mathrm{Lu}$ ) and tend to concentrate in the silicate melts. So, the REEs tend to concentrate in the residual magma and occur in the accessory minerals such as allanite, zircon, monazite, xenotime, apatite and sphene. The distribution of europium $(\mathrm{Eu})$ is particularly important because it unlike the other REEs. It occurs in two oxidation states, $\mathrm{Eu}^{+2}$ and $\mathrm{Eu}^{+3}$ depending on oxygen fugacity. Under the oxidizing conditions, $\mathrm{Eu}$ is trivalent $\mathrm{Eu}^{+3}$ and behaves as the other REEs, while under the reducing conditions, it occurs as divalent $\mathrm{Eu}^{+2}$ and has larger ionic radius replacing mainly $\mathrm{Ca}^{+2}$ in plagioclases and rarely $\mathrm{K}^{+}$in $\mathrm{K}$-feldspars.

The REE normalized patterns of the igneous rocks are controlled by the REE chemistry of their sources and the crystal-melt equilibria that have taken place during their evolution. So, the shape of the normalized REEs pattern is mainly related to the rock forming minerals, as well as the processes that affected the rock formation, like fractional crystallization, partial melting and/or assimilation. REE distribution patterns are usually considered as an important tracer for source rocks because 
the REE concentrations have few changes and little deformation to lost during rock weathering, sedimentation and diagenetic processes (Byrne and Sholkovitz, 1996; Nozaki et al., 1997; Lawrence and Kamber, 2006; Frimmel, 2009).

Eleven samples are collected from the investigated granitic samples (seven samples from monzogranite and four samples from associated pegmatite) were analyzed for REEs in the Egyptian nuclear materials authority labs (NMA) using ICP-AES, Perkin Elmer, and Optima 3000 instrument. The operating conditions are; nebulizer flow (1L/min), auxiliary flow $(1 \mathrm{~L} / \mathrm{min})$, plasma flow $(15 \mathrm{~L} / \mathrm{min})$, viewing light $(15 \mathrm{~mm})$ and $\mathrm{RF}$ power $(1200$ watts). The accuracy of the results was found to be in the range $5-10 \%$ for the rare earth elements. The results of these analyses are listed in Table (2).

In order to evaluate the relative fractionation trend within the REE group, their contents in the studied granites are normalized to chondrite values of Anders and Grevesse (1989) and plotted against REE atomic numbers. The normalized REE pattern of monzogranite and pegmatite samples exhibit a remarkable similarity in REE contents; revealed by the superposition of different trends of both LREE and HREE (Fig.34 and 35). Monzogranite and pegmatite samples show similar chondrite-normalized REE patterns and have clearly fractionated LREEs relative to HREEs and showi distinct negative Eu anomaly.

Table 2: Rare earth elements contents (ppm) in the study Batoga monzogranite and associated pegmatite

\begin{tabular}{|c|c|c|c|c|c|c|c|c|c|c|c|c|c|}
\hline \multirow[b]{2}{*}{ S. No. } & \multicolumn{8}{|r|}{ Granites } & \multicolumn{5}{|c|}{ Pegmatite } \\
\hline & S1 & S 2 & S3 & S 4 & S 5 & S 6 & S 7 & Av. $n=7$ & S8 & S9 & S10 & S11 & $\begin{array}{r}\text { Av. } \\
\mathrm{n}=4\end{array}$ \\
\hline $\mathrm{La}$ & 30.8 & 12.7 & 15.0 & 21.0 & 25.8 & 20.8 & 21.0 & 21.01 & 16.0 & 22.5 & 13.0 & 11.0 & 15.63 \\
\hline $\mathrm{Ce}$ & 59.0 & 31.0 & 37.2 & 50.8 & 55.7 & 43 & 58.8 & 47.93 & 39.4 & 54.6 & 33.4 & 28.3 & 38.93 \\
\hline Pr & 7.4 & 7.8 & 6.5 & 7.0 & 7.3 & 6.8 & 8.7 & 7.36 & 5.7 & 8.0 & 5.4 & 5.1 & 6.05 \\
\hline Nd & 116.5 & 63.0 & 60.8 & 76.3 & 94.7 & 85.3 & 73.4 & 81.43 & 93.8 & 67.2 & 38.0 & 44.0 & 60.75 \\
\hline $\mathrm{Sm}$ & 13.4 & 9.4 & 9.8 & 9.4 & 11.4 & 11.4 & 13.4 & 11.17 & 7.55 & 10.0 & 8.4 & 7.55 & 8.38 \\
\hline $\mathrm{Eu}$ & 0.7 & 0.3 & 0.5 & 0.6 & 0.8 & 0.9 & 0.6 & 0.63 & 0.5 & 0.2 & 0.1 & 0.2 & 0.25 \\
\hline Gd & 6.8 & 5.6 & 4.4 & 6.7 & 8.6 & 9.0 & 6.5 & 6.80 & 7.0 & 7.3 & 5.5 & 5.6 & 6.35 \\
\hline $\mathrm{Tb}$ & 1.9 & 1.74 & 1.8 & 1.5 & 1.7 & 1.8 & 1.35 & 1.68 & 1.5 & 1.8 & 1.2 & 1.1 & 1.40 \\
\hline Dy & 9.6 & 6.5 & 6.2 & 8.7 & 11 & 11.8 & 7.6 & 8.77 & 10.8 & 10 & 8.3 & 5.95 & 8.76 \\
\hline Ho & 2.8 & 1.4 & 1.4 & 1.8 & 2.2 & 2.5 & 1.6 & 1.96 & 1.75 & 2.5 & 1.7 & 1.62 & 1.89 \\
\hline $\mathrm{Er}$ & 6.4 & 4.0 & 3.6 & 5.1 & 7.0 & 8.0 & 5.0 & 5.59 & 3.3 & 9.0 & 5.7 & 3.7 & 5.43 \\
\hline $\mathrm{Tm}$ & 1.2 & 0.65 & 0.6 & 0.75 & 0.9 & 1.2 & 0.65 & 0.85 & 0.7 & 1.4 & 0.75 & 0.45 & 0.83 \\
\hline Yb & 6.6 & 5.5 & 5.0 & 6.2 & 8.35 & 8.0 & 5.25 & 6.41 & 6.0 & 8.6 & 5.4 & 6.7 & 7.18 \\
\hline Lu & 1.4 & 1.0 & 0.7 & 1.25 & 1.25 & 1.4 & 0.76 & 1.11 & 1.3 & 1.5 & 0.7 & 0.6 & 1.03 \\
\hline$\sum$ REE & 264.5 & 147.99 & 153.5 & 197.1 & 236.7 & 211.9 & 204.61 & 202.3 & 195.3 & 206.6 & 126.1 & 194.4 & 180.60 \\
\hline$\sum$ LREE & 227.8 & 124.2 & 129.8 & 165.1 & 195.7 & 168.2 & 175.9 & 169.5 & 163 & 162.5 & 98.3 & 161.1 & 146.20 \\
\hline $\bar{\Sigma} \mathrm{HREE}$ & 36.7 & 23.79 & 23.7 & 32.0 & 41.0 & 43.7 & 28.71 & 32.80 & 32.4 & 44.1 & 27.75 & 33.38 & 34.40 \\
\hline$(\mathrm{La} / \mathrm{Lu}) \mathrm{n}$ & 2.23 & 1.287 & 2.172 & 1.703 & 2.092 & 1.506 & 2.801 & 1.97 & 1.25 & 1.521 & 1.882 & 1.86 & 1.63 \\
\hline$(\mathrm{La} / \mathrm{Sm}) \mathrm{n}$ & 1.411 & 0.829 & 0.939 & 1.371 & 1.389 & 1.12 & 0.962 & 1.15 & 1.3 & 1.381 & 0.95 & 0.89 & 1.13 \\
\hline$(\mathrm{Gd} / \mathrm{Lu}) \mathrm{n}$ & 0.6 & 0.433 & 0.777 & 0.663 & 0.85 & 0.795 & 1.057 & 0.74 & 0.67 & 0.601 & 0.706 & 1.154 & 0.78 \\
\hline$(\mathrm{Eu} / \mathrm{Sm}) \mathrm{n}$ & 0.137 & 0.084 & 0.134 & 0.168 & 0.184 & 0.207 & 0.118 & 0.15 & 0.174 & 0.053 & 0.031 & 0.48 & 0.18 \\
\hline$(\mathrm{La} / \mathrm{Yb}) \mathrm{n}$ & 3.163 & 1.565 & 2.034 & 2.296 & 2.095 & 1.763 & 2.712 & 2.23 & 1.81 & 1.439 & 1.632 & 1.11 & 1.50 \\
\hline$(\mathrm{Tb} / \mathrm{Yb}) \mathrm{n}$ & 1.289 & 1.416 & 1.612 & 1.083 & 0.911 & 1.007 & 1.151 & 1.21 & 1.12 & 0.76 & 0.995 & 0.73 & 0.90 \\
\hline$(\mathrm{Gd} / \mathrm{Yb}) \mathrm{n}$ & 0.852 & 0.526 & 0.727 & 0.893 & 0.851 & 0.93 & 1.023 & 0.83 & 0.97 & 0.569 & 0.612 & 0.69 & 0.71 \\
\hline $\mathrm{Eu} / \mathrm{Eu}^{*}$ & 0.199 & 0.131 & 0.201 & 0.219 & 0.236 & 0.261 & 0.173 & 0.20 & 0.21 & 0.068 & 0.046 & 0.09 & 0.10 \\
\hline
\end{tabular}




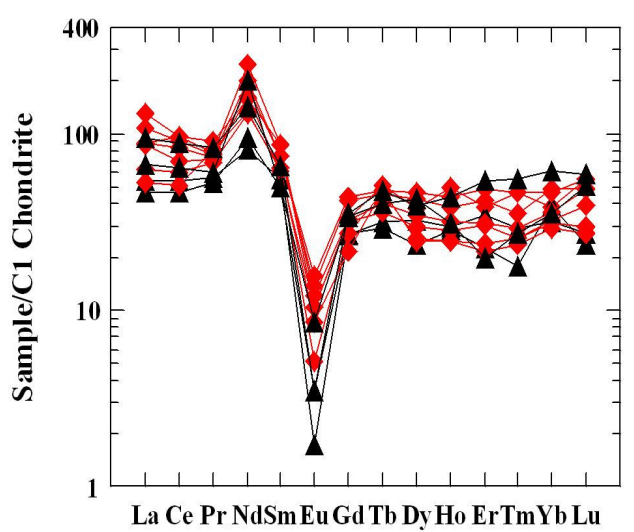

Fig.34: Normalized REE pattern of the studied monzogranite and associated pegmatite

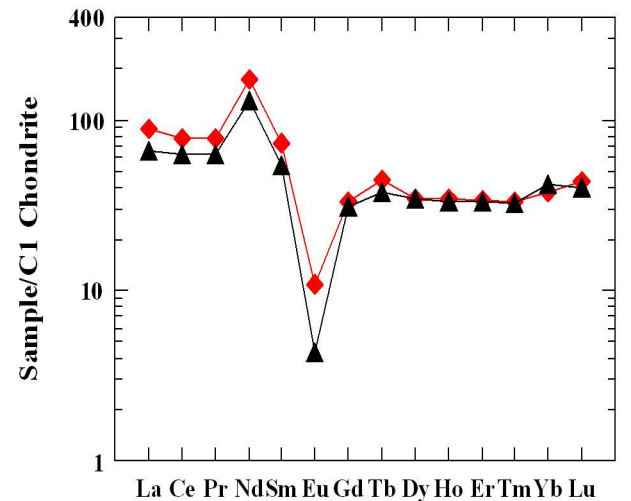

Fig.35: average normalized REE.(According to Anders and Grevesse,1989)

The analyzed monzogranite shows REE fractionation where $(\mathrm{La} / \mathrm{Lu})_{\mathrm{N}}$ vary from 1.29 to 2.8 with an average of 1.97 and 1.3 to 1.86 with an average of 1.63 for associated pegmatite samples (Table 2). They have relative enrichment of LREE contents in the analyzed monzogranite varying between $\sum$ LREE 124.2 to $227.8 \mathrm{ppm}$ with an average 169.95 . While the pegmatite, the LREE vary between $\sum$ LREE 98.3 to $162.95 \mathrm{ppm}$ with an average 146.2 ; (the average of $(\mathrm{La} / \mathrm{Sm})_{\mathrm{N}}$ range from 1.5 and 1.13 for these rocks, respectively (Table 2). The contribution of the REE bearing accessory minerals such as monazite, apatite, allanite and sphene represents potential contribution to the LREE concentration (Miller and Mittlefehldt 1982). This is confirmed by the petrographic study which shows that monzogranite contains sphene, allanite and apatite.

Concerning the HREE, The $\sum$ HREE vary from 23.7 to $43.7 \mathrm{ppm}$ with an average 32.8 for monzogranite and $\sum$ HREE varying between 27.75 and $44.1 \mathrm{ppm}$ with an average of 34.4 for associated pegmatite. Where the average of $(\mathrm{Gd} / \mathrm{Lu})_{\mathrm{n}}$ vary from 0.4 to 1.06 with an average of 0.74 for monzogranite and 0.67 to 1.15 with an average of 0.78 for the pegmatite samples (Table 2).

Strong negative Eu-anomaly which proposed by Henderson (1984) as $\left(\mathrm{Eu}_{\mathrm{n}}\right) /$ $\sqrt{ }\left(\mathrm{Sm}_{\mathrm{n}}\right)\left(\mathrm{Gd}_{\mathrm{n}}\right)$, when the value is $>1.0$ indicates positive anomaly while the value $<1.0$ is a negative anomaly. The rocks under consideration have $\left(\mathrm{Eu} / \mathrm{Eu}^{*}\right)_{\mathrm{n}}$ varying between 0.13 and 0.26 with an average of 0.2 for the monzogranite. While the analyzed pegmatite samples vary from 0.046 to $0.21 \mathrm{ppm}$ (Table2).

In fact the negative Eu anomalies is related to $\mathrm{Eu}^{2+}$ which compatible with plagioclase. These are explained by the crystal fractionation of plagioclase from the felsic granitic melt at low pressures (Neiva 1992), or partitioning into feldspar during fractionation (Singh et al. 2006). Another alternative explanation for the negative Eu-anomaly is based on the high oxygen fugacity $\left(f \mathrm{o}_{2}\right)$ in the granitic melt due to volatile saturation (Grenne and Roberts 1998). The oxygen activity of melt would be sufficiently high to keep Eu at the trivalent state and thus detains its incorporation into the accumulating plagioclase.

The depletion of the total REEs contents in monzogranites and associated pegmatite are 202.3 and $180.6 \mathrm{ppm}$ respectively which is less than the average of the world wide granites $(270 \mathrm{ppm})$ as given by Hermann (1970). The depletion of REEs has been attributed to various processes including magmatic differentiation (Cuney and Friedrich, 1987), hydrothermal leaching (Cathelineau \& Holliger, 
1987) and or a combination of both. The metasomatic process may also cause severe leaching of REE from the albitized granite. For example the REE depletion may be related to the transformation of accessory minerals such as monazite to apatite and thorite in some albitized granites (Boulvais et al., 2007).

Also, the slightly positive $\mathrm{Tb}$ anomaly (Fig.8a and b) in the studied samples is attributed to its preferential accommodation within the fluorite structure (Yonan, 1999). This is confirmed by the petrographic study which shows the monzogranite and pegmatite contains fluorite.

\section{CONCLUSIONS}

The studied monzogranite and associated pegmatites represent a part of the basement rocks of the Central Eastern Desert of Egypt. The pegmatites occur as elongated, small pockets and lenses exhibiting variation in color and display sharp contacts with the host granite. The pegmatites are characterized by obvious simple zonation. The common accessory minerals are zircon, allanite, fluorite, monazite, apatite and iron oxides.

The eU contents of the analyzed monzogranite samples range from $8 \mathrm{ppm}$ to $20 \mathrm{ppm}$ with an average 12 and the eTh contents range from $10 \mathrm{ppm}$ to $23 \mathrm{ppm}$ with an average 13.3. It is slightly higher than the average of granitic rocks, while the associated pegmatites, eU contents range from $28 \mathrm{ppm}$ to $355 \mathrm{ppm}$ with an average 134 and the eTh contents range from $24 \mathrm{ppm}$ to $210 \mathrm{ppm}$ with an average 97.6. It is worthy to mention that the altered granites belong to high-thorium, high-uranium granitic rocks where uranium is mostly located in the Th-rich accessory minerals as monazite, zircon and allanite. The studied monzogranites and associated pegmatites have low eTh/eU ratios indicating uranium enrichment.

The present study proved that radioactive minerals responsible for both $\mathrm{U}$ and $\mathrm{Th}$ contents in the studied monzogranite and associ- ated pegmatite are uranothorite, uranophane, zircon, monazite, allanite and fluorite.

The normalized REE pattern of monzogranite and associated pegmatite samples exhibit a remarkable similarity in REE contents that revealed by the superposition of different trends of both LREE and HREE. These samples show similar chondrite-normalized REE patterns and have clearly fractionated LREEs relative to HREEs, with distinct negative $\mathrm{Eu}$ anomaly.

REE bearing accessory minerals such as monazite, apatite, allanite and sphene represents potential source of LREEs. This is confirmed by the petrographic study. Strong negative Eu-anomaly could be explained by the crystal fractionation of plagioclase from the felsic granitic melts at low pressures or partitioning into feldspar during fractionation. Another alternative explanation for the negative Eu anomaly is based on the high oxygen fugacity $\left(\mathrm{O}_{2}\right)$ in the granitic melt due to volatile saturation. The depletion of REEs has been attributed to various processes including magmatic differentiation, hydrothermal leaching and or a combination of both. The slightly positive $\mathrm{Tb}$ anomaly in the studied samples is attributed to its preferential accommodation within the fluorite structure.

\section{REFERENCES}

Abdel-Monem, A. A.; El Amin, H. M; El Afandy, A. H; Hussein, A.H., and Abdel Aty, M.A., 1998. Petrological and geochemical characteristics of some younger granites bearing uranium mineralization: Recognition criteria of uranium province in Egypt. Proc. Egypt. Acad. Sci.,48, 213-270.

Adams, J.A.S. and Weaver, C.E., 1958. Thorium to uranium ratios as indications of sedimentary processes: example of concept of geochemical facies. Amer. Assoc. Petro. Geol. Bull., 42, 387-430.

Ammar, S.E., and Abd El Wahed, A.A., 2000. Uraniferous granitoids in the Eastern Desert of 
Egypt with special emphasis to the origin of the uranophane mineralization. Egypt. Mineral., 12, 107-126

Anders, E., and Grevesse, N., 1989. Abundances of the elements: Meteoritic and Solar. Geochimica et Cosmochimica Acta,53,197-214.

Anjos, R.M.; Veiga, R.; Soares, T.; Santos, A.; Aguiar, J.; Frascac, M.; Brage, J.; Uzeda, D.; Mangia, L.; Facure, A.; Mosquera, B.; Carvalho, C., and Gomes, P., 2005. Natural radionuclide distribution in Brazilian commercial granites. J. Radiat.Meas., 39, 245-253.

Assaf, H. S.; Ibrahim, M. E.; Ammar, S. E.; Saleh, G. M., and Rasheid, M. A., 1999. Geological and mineralogical studies on the radioactive mineral occurrence at Qash Amir area, Southeastern Desert, Egypt. Egypt. Miner., 11, 135156.

Bentor, Y.K.,1985. The crustal evolution of the Arabo-Nubian Massif with special reference to the Sinai Peninsula. Precambrian Research, 28,1-74.

Boulvais, P.; Ruffet, G.;Cornichet, J., and Mermet, M., 2007. Cretaceous albitization and dequartzification of Hercynian peraluminous granite in the Salvezines Massif (French Pyrénées) Lithos, 93, 89-106.

Byrne, R.H., and Sholkovitz, E.R.,1996. Marine chemistry and geochemistry of the lanthanides. In: $\mathrm{n}$ The Physics and Chemistry of Rare Earths ( Gschneidner, Jr. K.A., and Eyring, L., Eds.). 497-593.

Cathelineau, M., and Holliger, P.,1987. Polyphase metallogenesis of hydrothermal uranium veins from the southern amoricon massif, France. Proc. Int. Mtg Nancy., 212-217.

Cesborn, F.; Idefonse, P., and Sichere, M. D.,1993. New mineralogical data on uranophane and B-uranophane synthesis of uranophane. Ged. Magazine, 57, 301-308.

Charbonneau, B. W.,1982. Radiometric study of three granites in the Canadian Shield: Elliot lake, Ontario.In:Uraniumin Granites ( Smith; and Fury and Hecla, N. W. T.; in Maurice, Y. T.(Ed.). Geol. Surv. of Canada, 81-23, 91-99.

Cuney, M.,1978. Geologic environment, minerology and fluid inclusions of the Bois NorisLi-mouzat uranium vein, France. Econ. Geol., 73,1567-1610.

Cuney, M., and Friedrich, M.,1987. Physicochemical and crystal-chemical controls on accessory mineral paragenesis in granitoids: Implications for uranium metallogenesis. Bull. Mineral.,110, 235-247.

Dana, E.S.,1963. A textbook of mineralogy. John Wiley and Sons. Inc., New York and London, $851 p$.

Dawood, Y. H., and Abd El Naby, H. H.,2001. Mineralogy and genesis of secondary uranium deposits, Um Ara area, south Eastern Desert, Egypt. J. Afr. Earth, Sci., 32 (2), 317-323.

Deer, W. A.; Howie, R. A., and Zussman, J.,1962. An introduction to the rock forming minerals. Longman group limited, London, England. $621 \mathrm{p}$.

El Bayoumi, R. M.; Hassan, M. A.; Salman, A. B., and Abdallah, S. M.,1999. Subsurface geologic studies on Gebel El Missikat uranium occurrence, central Eastern Desert, Egypt. Proc. $4^{\text {th }}$ Inter. Conf. Geol. Arab World, Cairo Univ., Egypt. 541-564.

El Feky, M.G.; El Mowafy, A. A., and Abdel Warith, A.,2011. Mineralogy, geochemistry, radioactivity and environmental impacts of Gabal Marwa granites, southeastern Sinai, Egypt. Chin. J. Geochem., 30, 175-186.

El-Galy, M. M., 1998. Geology, radioactivity, geochemistry and tectonic setting of selected granitic rocks, West Gulf.

El- Kammar, A. M.; Salman., A. E.; Shalaby. H. M., and Mahdy, A. I.,2001. Geochemical and genetical constraints on rare metals mineralization at the central Eastern Desert of Egypt. Geochem. J., 35, 117-135. 
Frimmel, H.E.,2009. Trace element distribution in Neoproterozoic carbonates as palaeoenvironmental indicator. J. Chem. Geol., 258, $338-353$.

Förster, H.J., 2006. Composition and origin of intermediate solid solutions in the system thorite-xenotime-zircon-coffinite, Lithos, 1-4, 35-55.

Gascoyne, M., 1982.Geochemistry of the actinides and their daughters. In: Uranium series disequilibrium, applications to environmental problems( Ivanovich ,M.,and Harmon, R.S. , Eds.):33-55.

Grenne, T., and Roberts, D.,1998.The Holanda porphyrite, Norwegian Caledonides; geochemistry and tectonic setting of early-Mid Ordovician shoshonitic volcanism. J. Geol. Soc., London, 155, 131-142.

Heinrich, E.W., 1958. Mineralogy and geology of radioactive raw materials. McGraw Hill Book Company, New York. Inc., 295p.

Henderson, P.,1984. Rare earth elements geochemistry. El Sevier Sci. publ., New York. 510p.

Hermann, A. G.,1970. Yttrium and lanthanides. In: Handbook of geochemistry(Wedepohl,Ed.), Springerverlog, New York, U. S. A., 39-57.

Hughes, J. M.; Cameron, M., and Mariano, A. N.,1991. Rare earth ordering and structural variations in natural rare earth bearing apatite. Amer. Miner., 76, 1165-1173.

Hussein, A. A., 1978. Lecture course in nuclear geology. NMA, Egypt, 101p.

Lawrence, M.G., and Kamber, B.S., 2006. The behaviour of the rare earth elements during estuarine mixing-revisited. J. Marine Chemistry. $100,147-167$.

Matoline, M.,1991. A report to the government of the Arab Republic of Egypt. "Construction and use of spectrometric calibration pads", Egypt. Laboratory gamma-ray spectrometry.

Miller, C. F., and Mittlefehldt, D. W.,1982. Deple- tion of light rare earth elements in felsic magma. Geol.,10, 129-133.

Mohamed, N. A.,1995. Distribution and extraction of uranium and some trace elements from the mineralized zones of El Missikat-El Erediya area, Central Eastern Desert, Egypt. Ph. D. Thesis, Cairo Univ., Egypt. 185p.

Neiva, A. M. R.,1992. Geochemistry and evolution of Jales granitic system. Northern Portugal. Chem. Erde., 52, 225-241.

Nozaki, Y.; Zhang Jing, and Amakawa, H.,1997. The fractionation between $\mathrm{Y}$ and Ho in the marine environment. J. Earth and Planetary Sci. Letters. 148, 329-340.

Raslan, M.F.; El-Shall, H.E.; Omar, S.A., and Daher, A.M., 2010a. Mineralogy of polymetallic mineralized pegmatite of Ras Baroud granite, Central Eastern Desert, Egypt. J. Mineral. \& Petrol. Sci., 105, 123-134.

Raslan, M.F.; Ali, M.A., and El feky, M.G.,2010b. Mineralogy and radioactivity of pegmatites from South Wadi Khuda area, Eastern Desert, Egypt. Chinese J. Geochemistry, 29, 343354.

Reeves, R.D., and Brooks, R.R.,1978. Trace element analyses of geological materials. John Wiley \& sons Inc., New York, 421p.

Rogers, J. J. W., and Adams, J. A. S.,1969. Uranium and thorium. In: Handbook of geochemistry (Wedepohl, K. H.,Ed.). VII-3, 92-B-1 to 92-0-8 and 90-B-1 to 90-0-5, Springer Verlag, Berlin.

Sadek, A.A.,2005. Geology, geochemistry and radioactivity of $\mathrm{Abu}$ Fahm area with special emphasis on the granitic rocks, central Eastern Desert, Cairo, Egypt. Cairo Univ.,362p.

Shalaby, M.H.,1996. Structural controls of uranium mineralization of Gabal Qattar, north Eastern Desert, Egypt. Proc. Egypt. Acad. Sci., 46, 521-536.

Shelley, D., 1993. Igneous and metamorphic rocks under microscope, Chapman \& Hill, London, 
$405 p$.

Shives, R.B.K.; Ford, K.L., and Charoneau, B.W.,1995. Application of gamma-ray spectrometric/magnetic/LF-EM surveys-Workshop Manual. J. Geol. Surv. Canada, Open File. $3061,82$.

Simpson, P. R.; Brown, G. C.; Plant, J., and Ostle, D., 1979. Uranium mineralization and granite magmatism in the British Isles. Phil. Trans. R. Soc. London, A. 291,385-412.

Singh, R. K. B., and Vallinayagan, G., 2006. Anorogenic acid volcanic rocks in the Kundal area of the Malani igneous suite, North western India; Geochemical and petrogenitic studies. J. Asian Earth Sciences, 1-14.
Stern, R. J., 1979. Late Precambrian crustal environments as reconstructed from relict igneous minerals, Central Eastern Desert of Egypt. Ann. Geol. Surv. Egypt. 9, 9-31.

Surour, A.A.; El-Bayoumi, R.M.; Attawiya, M.Y., and El-Feky, M.G., 2001. Geochemistry of wall rock alterations and radioactive mineralization in the vicinity of Hangaliya auriferous shear zone, Eastern Desert, Egypt. Egypt. J. Geol., 45(1), 187-212.

Yonan, A. A., 1999. Rare earth elements geochemistry as indicator for petrogenesis of Urf Abu Hamam granites, South Eastern Desert, Egypt; A case study of A-type granite-metallogenic relationship. Egypt. J. Geol., 43 (1), 275-286.

\footnotetext{
دراسات معدنية و إشعاعية وتمعدنات العناصر النادرة لمونزوجرانيت باتوجا

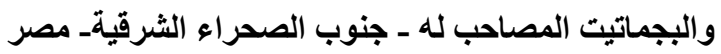$$
\text { عبدالمعز على صـادق و عبدالهادى احمد عباس }
$$$$
\text { تفع منطقة الدر اسة جنوب غرب ر أس بيناس بجنوب الصحر اء الثرقية، و التى تغطى بصخور الميتاجابرو و التوناليت }
$$$$
\text { و المنزوجر انيت الحاوى لصنور الإنة البجماتيت. }
$$

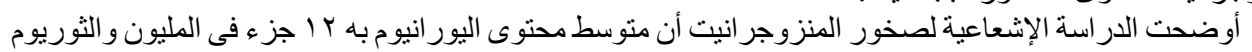

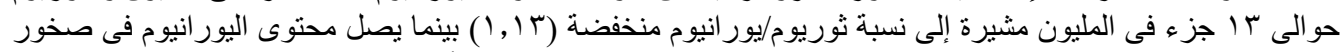

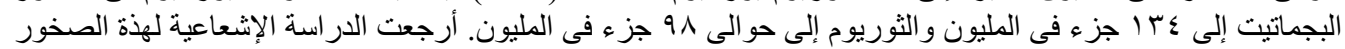

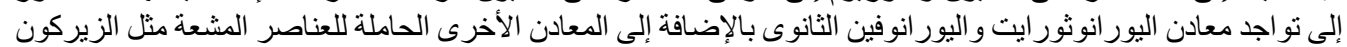$$
\text { و المونازيت و الألنيت و الفلوريت أنورايت. }
$$

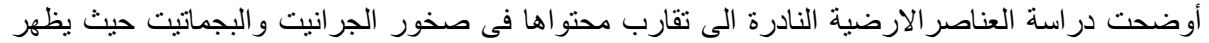

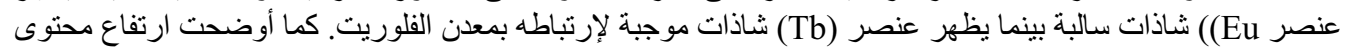

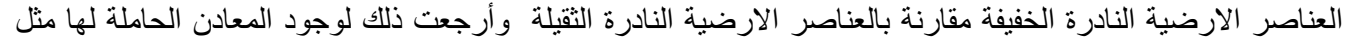

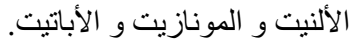

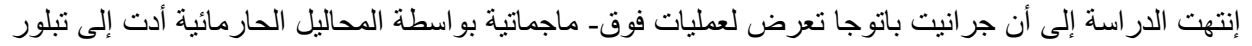

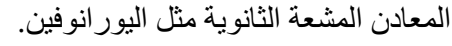

